\title{
Online customized T-shirt design and evaluation of online websites for customization
}

\author{
DOI: 10.35530/IT.071.04.1674
}

AHMET ÖZBEK

\section{ABSTRACT - REZUMAT}

\section{Online customized T-shirt design and evaluation of online websites for customization}

Customized clothing manufacturing is a clothing manufacturing method realized and performed in collaboration between the manufacturer and the customer. In this manufacturing method, the customer is offered a basic piece of clothing and various options (fabric, model, color, style, accessories, printing on clothing, etc.) so that the customer can modify the clothing and design the most suitable garment. Thanks to this manufacturing method, the customer has the opportunity to purchase the most appropriate personalized clothing while, at the same time, the manufacturer achieves a high profit margin by making a customized product. Customized clothing production is an important method in the industry because it increases both the profit margin of the enterprises and the level of customer satisfaction. Although it is not yet a very common method, it is expected that it will become widespread in the future with technological developments. Within the framework of this study, we focused on online customized T-shirt manufacturing. The study was carried out in three stages. In the first stage, the design options that young consumers prefer and/or need for online customized T-shirt design were determined. In the second stage, websites that perform the manufacturing of customized T-shirt that are available online in Turkey were determined. In the third stage, online T-shirt design options determined in the first stage were presented to the customers by the websites determined during the second stage. According to the assessment, customized T-shirt design websites active in Turkey were found to be adequate in terms of the "design with respect to body sizes" option. In addition, some design options that online personalized T-shirt design websites intend to offer change according to the gender and education of young consumers.

Keywords: product customization, T-shirt, clothing, website, customer

\section{Design personalizat online pentru tricouri și evaluarea site-urilor web pentru personalizare}

Fabricarea de îmbrăcăminte personalizată este o metodă de producție realizată printr-o colaborare între producător și client. În cadrul acestei metode de producție, clientului i se oferă un articol de îmbrăcăminte de bază și diverse opțiuni (material textil, model, culoare, stil, accesorii, imprimeu etc.), astfel încât acesta să îl poată modifica și să creeze combinația dorită. Datorită acestei metode de producție, clientul are posibilitatea de a achiziționa articole de îmbrăcăminte personalizate și, în același timp, producătorul atinge o marjă de profit ridicată realizând un produs personalizat. Producția de îmbrăcăminte personalizată este o metodă importantă în industrie, deoarece crește atât marja de profit a întreprinderilor, cât și nivelul de satisfacție a clienților. Deși nu este încă o metodă uzuală, se așteaptă ca în viitor să fie aplicată odată cu evoluția tehnologică. În cadrul acestui studiu, ne-am concentrat pe fabricare tricourilor personalizate. Studiul a fost realizat în trei etape. În prima etapă, au fost determinate opțiunile de design pe care le preferă tinerii consumatori și/sau necesitatea unui design online personalizat pentru tricouri. În a doua etapă, au fost identificate site-urile web care oferă posibilitatea personalizării tricourilor, disponibile online în Turcia. În cea de-a treia etapă, opțiunile de design online pentru tricouri, identificate în prima etapă, au fost prezentate clienților prin site-urile web identificate în cea de-a doua etapă. Conform evaluării, s-a constatat că site-urile web de design personalizate pentru tricouri, active în Turcia, sunt adecvate în ceea ce privește opțiunea „design care respectă dimensiunile corpului”. În plus, unele opțiuni de design pe care site-urile online de design personalizat pentru tricouri intenționează să le ofere se pot modifică în funcție de sex și de educația tinerilor consumatori.

Cuvinte-cheie: personalizare, tricou, îmbrăcăminte, site web, client

\section{INTRODUCTION}

In the past, consumers had to choose from existing products in spite of a lack of variety. As the number of producers in the following years increased the product range increased, and more variety was offered [1]. In addition, the increase in production and employment brought about socio-economic development and thus the living standards and quality of life of consumers began to improve [2]. Thus, consumers started to expect more from the producers. This has reached its most advanced stage in sectors such as clothing and footwear [3]. Not only are consumers demanding fashionable and innovative clothing at competitive prices, but they are also constantly changing their demands because of the desire for customized clothing and up to the minute fashion. As a result, clothing manufacturers are no longer able to meet the needs of different consumers with a single choice in clothing [3-4]. 
In addition to the changing demands of consumers, intense international competition in the sector has started to decrease the production levels and profit margins of clothing companies [5]. Business establishments are focused on meeting the needs of consumers (who are extremely knowledgeable, demanding, and self-absorbed), selling products to consumers repeatedly, and largely preserving their intention to buy products from them again. Therefore, consumers have started to find solutions to their problems such as time problems, discomfort, long queues, product problems, high prices, order problems, and inadequate options [6-8]. As a solution to these problems, they have concluded that the transition from productoriented production to customer-oriented production could be one of the desired solutions [9].

With the advent of computer-aided design (CAD), computer-aided manufacturing (CAM), 3D technologies, body scanning systems, and internet technologies, and the customer-oriented use of the clothing industry, customized manufacturing has started to develop [4, 10-13]. In customized manufacturing, where customers can change the production line of the company to produce products to their own design and requirements, production is carried out only according to the wishes of the customers, and the design is carried out jointly with the customer, including modular product designs, flexible processes, and supply chain integration with customized products at the determined place and time and featuring a technology-assisted manufacturing method [11, 13, 15]. Customized manufacturing provides significant advantages to both the business and the consumer. For the business, the advantages are advanced customer knowledge, a high profit margin, high customer satisfaction, the ability to reach more customers at a low cost, a long-term relationship with the customer, flexible production, low and/or non-stock production, new design garment production, reduction in waste, rapid flow of cash, no discount pricing, coping with market uncertainties, quick response to customer demands, and higher levels of customer loyalty. In terms of consumers, personalized production offers a variety of advantages including a unique shopping experience, flexibility, personalized clothing, a shorter delivery time, high satisfaction, and access to unique clothing at affordable prices [3, 7, 12, 14, 17-19]. Thanks to these advantages of customized manufacturing, the mass (batch) production of clothes is reduced, and the cost-effective production of highquality clothing for consumers is increased [16].

Customized manufacturing has some differences from traditional mass production. Customized manufacturing consists of two stages. The first stage is where the enterprise establishes a flexible customization system that meets the needs of the overall consumer profile. The second stage is where consumers personalize their common design products using the options offered to them [4, 16, 20].

Clothing has significant potential for customized manufacturing because of its versatility, modular characteristics, and the nature of self-expression
[21]. Customized manufacturing in the clothing industry consisted, at first, of phases such as measuring the customer's body size by an employee and then entering the size into the computer as well as the customer's preferred clothing characteristics; then the fabric was determined according to the specified size, the fabric was cut into pieces and then assembled into a garment, and finally, the garment was presented to the customer [12]. However, the development of body scanners, 3D virtual clothing simulation, and the Internet and other technologies has eliminated many of the above steps. In the new situation, the customer can produce his or her own personalized garment by using the internet and other technologies without the need to go to the business establishment for measurements and choices [5, 22]. In this production method, enterprises have the opportunity to meet the current customer requirements and recapture the efficiency advantages they had previously provided in mass production [6].

Customized manufacturing was realized in the early days of the clothing sector by offering the consumer some very simple options (such as printing on the garment, printing elements such as shapes) [11]. With the development of technology, customized manufacturing can now offer unlimited choice to the consumer (choosing the most appropriate model from the basic garment samples and then choosing the fabric, model, color, style, accessories, etc. on the basic garment the customer has chosen), and this industry continues to develop [23].

The manufacturing of customized clothing started commercially in the 1990s with related implementations by clothing business enterprises such as Levi Strauss (Second Skin Swimwear and Custom Foot), Nike (Nikeid and Lands-End) and Adidas (miadidas) [10]. An increasing number of apparel manufacturers (e.g. Polo Jeans) and retailers of different sizes (e.g. Lands' End) and some fully online business enterprises (e.g. Threadless, Zazzle) have solidified their advantage as precursors and adopted the production of customized garments [5]. Furthermore, more and more consumers are demanding personalized clothing every day [2]. So much so that clothing retailer Land's End has found that online customized manufacturing has a strong and positive impact on consumer loyalty [24].

In customized manufacturing, it is important that information transfer between the enterprise and the customer takes place instantly and efficiently and that customers can view the final prototype online [3, 10]. For this reason, there is a need for advanced production technologies, flexible management techniques, and especially information technologies for customized manufacturing [25]. The internet is the medium for technology that can best provide this relationship today [17]. For this reason, fashion products have begun to be customized widely with computer technology via the internet [25]. For example, Khan et al. [26] developed a web-based portal for obese consumers to purchase customized clothing online with simple, easy steps. This portal allows the 
customer to design clothes according to their personal body size, create their own style, and choose the fabric. Nike provides an online platform for customers to order customized products. Through this platform, customers can select products and print their names on them. In addition, customers can make some customizations using the options on the semi-finished standard product [11]. As seen in the examples, online customized manufacturing has begun to turn into a commercial advantage [24].

As a result, although online customized clothing production is new, its use in daily life increases with developments in technology. Because of this feature, it is foreseen that the usage of customization and its importance in the clothing sector will continue to increase. The aim of this study is to determine the customers' choices and needs oriented options and to evaluate the customized T-shirt manufacturing websites available currently in Turkey in terms of their ability to provide the determined choices within the scope of this research.

\section{MATERIAL AND METHOD}

The implementation section of the research consists of three stages. In the first stage, the design options that consumers prefer and/or need for online customized T-shirt design were determined. In the second stage, customized T-shirt design websites available online in Turkey were determined. In the third and final stage, the providing of consumers with options outlined within the scope of the research in the context of websites that perform online customized T-shirt production situation in Turkey was evaluated. The flow diagram of the research study is given in figure 1.

Stage 1: Identifying and determining online customized T-shirt design options

In this study, qualitative-quantitative research methods were used together. In this context, both questionnaire and interview techniques were used during the data collection phase of the study [27]. Due to the scope of the research regarding internet use and the proportion of young people in Turkey who shop online, it was designated as the universe of the study. According to Turkey Statistical Institute (TSI) the population of young people in Turkey is 12,983,097 [28]. YÖK (Higher Education Council) states that 59.62\% of young people in Turkey $(7,740,502)$ are university

students [29]. Thus, university students were chosen as the sample for the study. In addition, the T-shirt was chosen as the item of customized online clothing because of its simplicity of manufacturing compared to other garments and its high rate of purchase by young people.

The survey method was used to determine the choices that young consumers need and/or prefer for designing online customized T-shirts. For the design of the related questionnaire, firstly the literature was examined, and then a face-to-face interview was conducted with 25 students from Sinop University. The questionnaire, which was composed of data obtained from these two sources, consisted of two parts. In the first part, there are five multiple-choice questions about the socio-economic characteristics of the participants. In the second part, there are 14 options regarding the elements that young consumers need and/or prefer for an online customized T-shirt design which consisted of a five-point Likerttype response set: $1=$ not important at all, $2=$ less important, 3= reasonably important, $4=$ mportant, $5=$ very important.

The questionnaire was applied to a group of 60 people and tested. The data obtained as a result of the application was subjected to reliability analysis and Cronbach's alpha value $(\alpha)$ was found to be 0.853 . Since this value shows that the questionnaire can provide the desired data for the research [30], the survey was published on the website www.surveey.com between 05.12.2017 and 30.12.2017 in order to reach all university students. 847 university students completed the questionnaire, but only $66.8 \%$ (566) of them were considered valid due to deficiencies in the questionnaires completed. Survey data were evaluated with the IBM SPSS Statistics Data Editor program, and the results are given below.

In terms of gender distribution, $61.6 \%$ (349) of the students were women, $33.3 \%$ (189) were men, and $4.9 \%$ (28) did not answer this question. There were 566 participants in total. Distribution of participants according to age groups was 17, 18, 19, 20, 21, 22, and 23 and over. The largest percentage of women was in the 19 age group, $27.0 \%$ (96), and the largest percentage of men were in the 21 age group, $20.0 \%$ (39).

The distribution of the educational status of the participants is given in table 1. According to the table, more than $90 \%$ of the partici-

STAGE 1: Identifying consumers' needs and/or preferred design options for online customized T-shirt design ए

STAGE 2: Determining available online customized T-shirt design websites in Turkey

STAGE 3: Evaluating the options determined in Stage 1 according to the presence of the websites determined in Stage 2 in terms of offert to consumers

Fig. 1. Flow Diagram of the research study pants had an associate's degree and an undergraduate education. In addition, $49.9 \%$ (174) of the participants were women with an undergraduate education, and $49.2 \%$ (93) were men with an associate's degree. The distribution of the participants according to their monthly income is given in table 2. According to the 


\begin{tabular}{|l|c|c|c|c|c|c|}
\hline \multicolumn{7}{|c|}{ DISTRIBUTION OF PARTICIPANTS ACCORDING TO EDUCATION LEVEL } \\
\hline \multirow{2}{*}{ Education status } & \multicolumn{2}{|c|}{ Female } & \multicolumn{2}{c|}{ Male } & \multicolumn{2}{c|}{ Total } \\
\cline { 2 - 7 } & Number & Frequency (\%) & Number & Frequency (\%) & Number & Frequency (\%) \\
\hline Associates Students & 162 & 46.4 & 93 & 49.2 & 255 & 47.4 \\
\hline Bachelor's Students & 174 & 49.9 & 88 & 46.6 & 262 & 48.7 \\
\hline Postgraduate Students & 13 & 3.7 & 8 & 4.2 & 21 & 3.9 \\
\hline Total & 349 & 100 & 189 & 100 & 538 & 100 \\
\hline *UAN & \multicolumn{7}{|c|}{28} & & \\
\hline
\end{tabular}

Note: *Number of participants who did not answer this question (UAN)

\begin{tabular}{|c|c|c|c|c|c|c|}
\hline \multicolumn{7}{|c|}{ DISTRIBUTION OF PARTICIPANTS ACCORDING TO MONTHLY REVENUES } \\
\hline \multirow{2}{*}{ Income } & \multicolumn{2}{|c|}{ Female } & \multicolumn{2}{|r|}{ Male } & \multicolumn{2}{|r|}{ Total } \\
\hline & Number & Frequency (\%) & Number & Frequency (\%) & Number & Frequency (\%) \\
\hline $0-250 \mathrm{TL}$ & 56 & 15.9 & 15 & 7.7 & 71 & 12.9 \\
\hline $251-500 \mathrm{TL}$ & 115 & 32.6 & 49 & 25.1 & 164 & 29.9 \\
\hline $501-750 \mathrm{TL}$ & 74 & 21 & 36 & 18.5 & 110 & 20.0 \\
\hline 751-1000 TL & 27 & 7.6 & 21 & 10.8 & 48 & 8.7 \\
\hline $1001-1250 \mathrm{TL}$ & 29 & 8.2 & 15 & 7.7 & 44 & 8.0 \\
\hline $1251-1500 \mathrm{TL}$ & 17 & 4.8 & 24 & 12.3 & 41 & 7.4 \\
\hline $1501 \mathrm{TL}$ and over & 35 & 9.9 & 35 & 17.9 & 70 & 12.7 \\
\hline Total & 353 & 100 & 195 & 100 & 548 & 100 \\
\hline UAN & & & & 18 & & \\
\hline
\end{tabular}

table, $29.9 \%$ (164) of the participants had a monthly income of $251-500 \mathrm{TL}$. The proportion of the participants with income of TL 1001 or more is approximately $28.2 \%$. In addition, $32.6 \%$ (115) of the female participants and $25.1 \%$ (49) of the male participants had a monthly income of 251-500 TL.

Table 3 shows the data on the participants' desire to find suitable T-shirts, purchase clothes online, and design customized T-shirts online. According to the table, $40.0 \%$ (142) of the female participants and
$46.6 \%(90)$ of the male participants could not find an appropriate T-shirt. $73.5 \%$ (261) of the female participants and $63.7 \%$ (123) of the male participants buy clothes online. Again, according to the data, women buy more clothes online than men. In addition, $83.1 \%$ (294) of the female participants and $87.9 \%$ (145) of the male participants had the desire to design online customized T-shirts. These data were perceived as need for online customized T-shirts manufacturing in Turkey.

DISTRIBUTIONS ACCORDING TO THE DESIRE OF PARTICIPANTS TO FIND T-SHIRT SUITABLE FOR THEIR TASTE, TO PURCHASE ONLINE CLOTHING, AND TO DESIGN A CUSTOMIZED T-SHIRT ONLINE

\begin{tabular}{|c|c|c|c|c|c|c|c|}
\hline \multirow{2}{*}{\multicolumn{2}{|c|}{ Answers }} & \multicolumn{2}{|c|}{$\begin{array}{c}\text { Status of the participants } \\
\text { finding T-shirt duitable } \\
\text { to their desire }\end{array}$} & \multicolumn{2}{|c|}{$\begin{array}{c}\text { Status of the participants } \\
\text { wishing to purchase T-shirt } \\
\text { online }\end{array}$} & \multicolumn{2}{|c|}{$\begin{array}{c}\text { Status of the participants } \\
\text { wishing to design T-shirt } \\
\text { online }\end{array}$} \\
\hline & & Number & Frequency (\%) & Number & Frequency (\%) & Number & Frequency (\%) \\
\hline \multirow[t]{2}{*}{ Female } & Yes & 213 & 60 & 261 & 73.5 & 294 & 83.1 \\
\hline & No & 142 & 40 & 94 & 26.5 & 60 & 16.9 \\
\hline \multirow[t]{2}{*}{ Male } & Yes & 103 & 53.4 & 123 & 63.7 & 145 & 87.9 \\
\hline & No & 90 & 46.6 & 70 & 36.3 & 20 & 12.1 \\
\hline \multirow[t]{2}{*}{ Total } & Yes & 316 & 57.6 & 384 & 70.0 & 439 & 84.5 \\
\hline & No & 232 & 42.3 & 164 & 29.9 & 80 & 15.4 \\
\hline \multicolumn{2}{|c|}{ Answered number } & \multicolumn{2}{|r|}{548} & \multicolumn{2}{|r|}{548} & \multicolumn{2}{|c|}{519} \\
\hline \multicolumn{2}{|l|}{ UAN } & \multicolumn{2}{|r|}{18} & \multicolumn{2}{|r|}{18} & \multicolumn{2}{|r|}{47} \\
\hline
\end{tabular}


DISTRIBUTION OF PARTICIPANTS ACCORDING TO THE NUMBER OF T-SHIRTS THAT THEY WANT TO BUY BY DESIGNING ONLINE IN ONE YEAR

\begin{tabular}{|l|c|c|c|c|c|c|}
\hline \multirow{2}{*}{ T-shirts orders } & \multicolumn{2}{|c|}{ Female } & \multicolumn{2}{c|}{ Male } & \multicolumn{2}{c|}{ Total } \\
\cline { 2 - 7 } & Number & Frequency (\%) & Number & Frequency (\%) & Number & Frequency (\%) \\
\hline 1-2 Pieces & 34 & 11.5 & 23 & 15.8 & 57 & 12.9 \\
\hline 3-4 Pieces & 56 & 18.9 & 21 & 14.4 & 77 & 17.4 \\
\hline 5-6 Pieces & 71 & 24.0 & 35 & 24.0 & 106 & 23.9 \\
\hline 7-8 Pieces & 37 & 12.5 & 12 & 8.2 & 49 & 11.0 \\
\hline 9 and Over Pieces & 98 & 33.1 & 55 & 37.7 & 153 & 34.6 \\
\hline Total & 296 & 100 & 146 & 100 & 442 & 100 \\
\hline UAN & \multicolumn{7}{|l|}{124} & & \\
\hline
\end{tabular}

Table 4 shows the number of T-shirts that the participants would like to design and purchase online in one year. According to the table, $34.6 \%$ (153) of the participants were willing to purchase and design nine or more online customized T-shirts per year. Also, according to gender; $33.1 \%$ (98) of the female participants and $37.7 \%(153)$ of the male participants had the desire to design and purchase nine or more customized online T-shirts in one year.

Factor analysis was performed with the IBM SPSS Statistics Data Editor program to respond to consumers' needs and/or preferred options for online customized T-shirt design. In factor analysis, factor loads of 0.500 and above were considered to be quite good, and questions with factor loads below this value were excluded from the analysis [30]. According to the results of the analysis, the factor load of the option to use more than one color in a T-shirt was 0.441 , and the factor load of the various sewing thread options was 0.492 ; the factor analysis was performed twice. Table 5 shows the results of the factor analysis and explains the total variance. While the total variance explained in the first case was $58.251 \%$, when these options were excluded from

Table 5

\begin{tabular}{|l|c|}
\hline \multicolumn{2}{|c|}{ FACTOR ANALYSIS RESULTS } \\
\hline \multicolumn{2}{|c|}{ Options } \\
(Declared total variance 63.603\%) & $\begin{array}{c}\text { Factor } \\
\text { loadings }\end{array}$ \\
\hline Wide variety of fabrics & 0.846 \\
\hline Wide range of fabric colors & 0.719 \\
\hline Wide range of collar types & 0.601 \\
\hline Design according to body sizes & 0.689 \\
\hline Wide variety of T-shirt cuts & 0.759 \\
\hline Determining the length of the shirt & 0.799 \\
\hline Determining the sleeve length of the T-shirt & 0.749 \\
\hline Printing on the desired area of the T-shirt & 0.761 \\
\hline $\begin{array}{l}\text { Identifying auxiliary materials such as } \\
\text { button, zipper, etc. }\end{array}$ & 0.707 \\
\hline Determination of pocket size and location & 0.709 \\
\hline Printing photos on a T-shirt & 0.709 \\
\hline Original design & 0.550 \\
\hline
\end{tabular}

the analysis, the total variance explained was $63.603 \%$ and the factor loadings increased to 0.500 as shown in table 5 .

In addition, according to the factor analysis, the KMO and Bartlett's Test value was obtained as 0.875 , and the analysis was continued because this value was higher than 0.500 . The reliability analysis was then performed, and the options derived from the factor analysis results were not included in the analysis. Accordingly, Cronbach's alpha, the value of the answers for the choices was found to be 0.875 . Since this value was between $0.80 \leq \alpha<1.00$, it was found that the questionnaire for options was highly reliable [30].

Table 6 presents the average and standard deviation values of the participants' responses to the items required by consumers for online customized T-shirt design.

The arithmetic means and standard deviations in Table 6 were calculated regarding the answers

Table 6

AVERAGE AND STANDARD DEVIATION VALUES OF ONLINE PERSONALIZED T-SHIRT DESIGN OPTIONS

\begin{tabular}{|l|c|c|}
\hline \multicolumn{1}{|c|}{ Options } & Mean & $\begin{array}{c}\text { Std. } \\
\text { Deviation }\end{array}$ \\
\hline Design according to body sizes & 4.43 & 0.639 \\
\hline Original design & 4.30 & 0.662 \\
\hline Determining the length of the shirt & 4.29 & 0.682 \\
\hline Wide range of collar types & 4.27 & 0.652 \\
\hline Wide range of fabric colors & 4.26 & 0.689 \\
\hline Wide variety of T-shirt cuts & 4.20 & 0.743 \\
\hline $\begin{array}{l}\text { Determining the sleeve length of } \\
\text { the T-shirt }\end{array}$ & 4.16 & 0.727 \\
\hline Wide variety of fabrics & 4.14 & 0.694 \\
\hline $\begin{array}{l}\text { Identifying auxiliary materials such } \\
\text { as button, zipper, etc }\end{array}$ & 4.09 & 0.761 \\
\hline $\begin{array}{l}\text { Printing on the desired area of the } \\
\text { T-shirt }\end{array}$ & 4.04 & 0.773 \\
\hline $\begin{array}{l}\text { Determination of pocket size and } \\
\text { location }\end{array}$ & 3.83 & 0.830 \\
\hline Printing photos on a T-shirt & 3.76 & 0.886 \\
\hline
\end{tabular}


obtained from the 566 participants. It is at the top of the table because the standard deviation was small and the estimation was definite. Arithmetic means are given in order of magnitude. Thus, while the importance given to the first estimation is most evident, it can be seen that, as the list goes down, the importance given to expressions decreases.

Of the 566 participants, $447(72.6 \%)$ responded to the design according to size statement. The average of the answers given to this statement was 4.43 , and the standard deviation was 0.639 . These data show that the statement for the design according to body sizes was perceived as very important by the participants.

Of the 566 participants, 446 (72.4\%) answered the original design question. The average of the responses given to expression was 4.30 and the standard deviation was 0.662 . These data show that original design expression was perceived as very important by the participants.

Of the total of 566 participants, 444 (72.1\%) answered the about determining the length of the T-shirt. The average of the answers given to the statement was 4.29 and the standard deviation was 0.682 . These data indicate that the T-shirt length determination question was perceived as very important by the participants.

Of the 566 participants, 447 (72.6\%) answered the photograph print question. The average of the answers given to the question was 3.76 and the standard deviation was 0.886 . This shows that the expression of printing photos on a T-shirt was perceived by the participants as moderately important. Of the 566 participants, $443(71.9 \%)$ answered the question about determining the size and location of the pocket. The average of the answers given to the question was 3.83 and the standard deviation was 0.830 . This shows that the expression of the measure and location of the pocket was perceived by the participants as moderately important.

In addition, age, gender, education, and income status of young consumers and their relationship to design options that online personalized T-shirt design websites are intended to provide were investigated. For this purpose, four hypotheses were developed:

$\mathbf{H}_{\mathbf{1}}$ : There is a relationship between the age of young consumers and the design options that online personalized T-shirt design websites offer.

$\mathbf{H}_{\mathbf{2}}$ : There is a relationship between the gender of young consumers and the design options that online personalized T-shirt design websites offer.

$\mathbf{H}_{3}$ : There is a relationship between the education of young consumers and the design options that online personalized T-shirt design websites are required to offer.

$\mathbf{H}_{\mathbf{4}}$ : There is a relationship between the income of young consumers and the design options that online personalized T-shirt design websites offer.

The results of the correlation analysis to determine the relationships between the participants' age, gender, education, and income status, and the design options that online customized T-shirt design websites are required to present are shown in table 7.

According to table $7, \mathrm{H}_{1}$ and $\mathrm{H}_{4}$ hypotheses were rejected as there was no relationship between the age and income of young consumers and the design options that online personalized T-shirt design websites intended to offer. This shows that the design

\begin{tabular}{|l|c|c|c|c|c|c|c|c|}
\hline \multicolumn{7}{|c|}{ CORRELATION ANALYSIS RESULTS } \\
\hline \multirow{2}{*}{ Options } & \multicolumn{2}{|c|}{ Age } & \multicolumn{2}{c|}{ Gender } & \multicolumn{2}{c|}{ Education } & \multicolumn{2}{c|}{ Income } \\
\cline { 2 - 10 } & $\begin{array}{c}\text { Pearson } \\
\text { correlation }\end{array}$ & Sig. & $\begin{array}{c}\text { Pearson } \\
\text { correlation }\end{array}$ & Sig. & $\begin{array}{c}\text { Pearson } \\
\text { correlation }\end{array}$ & Sig. & $\begin{array}{c}\text { Pearson } \\
\text { correlation }\end{array}$ & Sig. \\
\hline Wide variety of fabrics & -0.079 & 0.105 & $-0.131^{* *}$ & 0.007 & -0.046 & 0.340 & 0.056 & 0.252 \\
\hline Wide range of fabric colors & 0.005 & 0.922 & $-0.146^{* *}$ & 0.003 & -0.045 & 0.360 & 0.005 & 0.922 \\
\hline Wide range of collar types & 0.072 & 0.139 & -0.039 & 0.423 & $-0.100^{*}$ & 0.040 & 0.024 & 0.618 \\
\hline Design according to body sizes & 0.072 & 0.142 & -0.073 & 0.133 & -0.040 & 0.411 & -0.046 & 0.349 \\
\hline Wide variety of T-shirt cuts & 0.042 & 0.390 & -0.057 & 0.244 & $-0.134^{* *}$ & 0.006 & 0.024 & 0.629 \\
\hline Determining the length of the T-shirt & -0.049 & 0.319 & $-0.096^{*}$ & 0.049 & $-0.136^{* *}$ & 0.005 & 0.077 & 0.116 \\
\hline $\begin{array}{l}\text { Determining the sleeve length of the } \\
\text { T-shirt }\end{array}$ & -0.070 & 0.153 & -0.040 & 0.417 & $-0.129^{* *}$ & 0.008 & 0.043 & 0.378 \\
\hline $\begin{array}{l}\text { Printing on the desired area of the } \\
\text { T-shirt }\end{array}$ & 0.031 & 0.527 & -0.020 & 0.686 & -0.019 & 0.696 & -0.034 & 0.483 \\
\hline $\begin{array}{l}\text { Identifying auxiliary materials such as } \\
\text { button, zipper, etc. }\end{array}$ & 0.041 & 0.398 & $-0.114^{*}$ & 0.020 & -0.039 & 0.426 & 0.001 & 0.989 \\
\hline $\begin{array}{l}\text { Determination of pocket size and } \\
\text { location }\end{array}$ & 0.036 & 0.463 & $-0.099^{*}$ & 0.044 & -0.095 & 0.052 & 0.073 & 0.137 \\
\hline Printing photos on a T-shirt & -0.053 & 0.280 & -0.005 & 0.923 & $0.109^{*}$ & 0.025 & -0.076 & 0.120 \\
\hline Original design & -0.023 & 0.633 & $-0.127^{* *}$ & 0.009 & -0.012 & 0.811 & -0.031 & 0.521 \\
\hline
\end{tabular}

Note: ${ }^{* *}$ Correlation is significant at the 0.01 level (2-tailed) and * Correlation is significant at the 0.05 level (2-tailed). 
options that online personalized T-shirt design websites intend to offer do not change according to these factors. However, the $\mathrm{H}_{2}$ and $\mathrm{H}_{3}$ hypotheses were accepted as it was determined that there was a relationship between the gender and education of young consumers and the design options that online personalized T-shirt design websites intended to offer. This suggests that with the change in gender and educational level of young consumers, the design options that online personalized T-shirt design websites are required to offer do change. The identified relationship is a significant and negative relationship between gender and education and the design options that consumers are required to offer online personalized T-shirt design websites.

Stage 2: Determining the online customized T-shirt design websites available in Turkey

In order to identify online T-shirt design websites that are active in Turkey, personalized search was made using the Google search engine. As a result of the search, it was seen that relevant websites generally originated from abroad. In Turkey, only eight online T-shirt design websites were identified. All of these websites were included in the research. However, the names of the websites were hidden by giving a code to each website because of the legal difficulties and time issues that would arise from attempting to obtain permission for research from the related websites. Codes given to websites were formed by the following letters: A, B, C, D, E, F, G and $\mathrm{H}$.

Stage 3: Evaluation and assessment of online customized T-shirt design websites

For the websites that already offer online customized T-shirts in Turkey, the condition of providing consumers with options specified in the first stage was evaluated in this section. In order to carry out the evaluation, a team of three experts consisting of an e-commerce expert, a fashion designer, and a garment manufacturing expert was formed. The team visited the designated online customized T-shirt production websites together and evaluated their availability to customers. The evaluation results are given in table 8 . Online personalized T-shirt production sites evaluated according to table 8 were found to be sufficient in terms of size design, which is the most preferred option for young consumers. Also, in terms of the option of printing photos on a T-shirt, C, D and G websites were found to be sufficient in terms of the option to print the desired region of the T-shirt; $D$ and $G$ websites in terms were found to be sufficient in terms of a wide variety of T-shirt cut options; the F website was found to be sufficient in offering a wide range of fabric color options; and $A, B, F$, and $E$ sites were found to be sufficient. However, online customized T-shirt manufacturing websites were found to be insufficient and inadequate in terms of offering a wide variety of fabric, collar types, T-shirt length determination, T-shirt sleeve length determination, determination of auxiliary materials such as buttons, zippers etc., determination of the size and location of the pocket, and to offering original design options.

\section{DISCUSSION}

The production of online customized clothing has been a topic that has been studied since the 1990s. The first examples of this production were implementations where customers chose the product, the customer's name was printed on the selected product through an online platform performed by Nike and some other businesses. These were followed by implementations where customers could make some personalizations and customizations using limited options on a semi-finished standard garment. In the course of time, applications started to emerge, even though at a simple level, according to the customer's body sizes. An example of these applications is Khan et al. [26], a portal that allows obese consumers to

EVALUATION AND ASSESSMENT OF ONLINE CUSTOMIZED T-SHIRT DESIGN WEBSITES AVAILABLE IN TURKEY

\begin{tabular}{|l|c|c|c|c|c|c|c|c|}
\hline \multicolumn{1}{|c|}{ Options } & \multicolumn{7}{c|}{ Web sites } \\
\cline { 2 - 9 } & A & B & C & D & E & F & G & H \\
\hline Wide variety of fabrics & - & - & - & - & - & - & - & - \\
\hline Wide range of fabric colors & + & + & - & - & + & + & - & - \\
\hline Wide range of collar types & - & - & - & - & - & - & - & - \\
\hline Design according to body sizes & + & + & + & + & + & + & + & + \\
\hline Wide variety of T-shirt cuts & - & - & - & - & - & + & - & - \\
\hline Determining the length of the shirt & - & - & - & - & - & - & - & - \\
\hline Determining the sleeve length of the T-shirt & - & - & - & - & - & - & - & - \\
\hline Printing on the desired area of the T-shirt & - & - & - & + & - & - & + & - \\
\hline Identifying auxiliary materials such as button, zipper, etc. & - & - & - & - & - & - & - & - \\
\hline Determination of pocket size and location & - & - & - & - & - & - & - & - \\
\hline Printing photos on a T-shirt & - & - & + & + & - & - & + & - \\
\hline Original design & - & - & - & - & - & - & - & - \\
\hline
\end{tabular}


design customized clothing online. However, there is still a need for studies in which the design options that consumers need and/or prefer are identified and presented to the consumer.

This study focused solely on the online design of T-shirts, focusing on whether the consumer was provided with desirable and/or preferred options for an online customized T-shirt design and evaluating the online customized T-shirt design sites with the aim of contributing to the design and development of online customized clothing design websites, thus differing from other studies.

In general, the results of the research show that today it is important for both the customer and the manufacturer to avoid loss of time by going to the manufacturer's shop to buy personal clothing. However, the customer needs to be able to enter his/her own body size on the website in order to purchase personal garments without going to the manufacturer's shop. However, this situation can cause problems due to incorrect measurement entries. One of the short-term solutions to the wrong measurement input problem is visual and easy-to-understand tools that customers can use to determine their own body size which can be developed and placed to personal design web sites. In the long run, the customers' avatars can be created in electronic medium according to their own dimensions. Thus, the customer will be able to design clothes for themselves using their avatars on the online personalized website and will be able to buy the garment by seeing the final form of the garment on them. It is foreseen that such developments will further increase the demand for online personal garment production.

\section{CONCLUSIONS}

As a consequence of the conducted study, of young consumers in Turkey, approximately $70 \%$ of them buy their clothes online, approximately $45 \%$ of them are unable to find T-shirts suitable for their tastes, $85 \%$ of them are willing to design online customized T-shirts, and $34.6 \%$ of them are willing to buy nine or more online customized designed T-shirts each year. Young consumers prefer online customized T-shirt for the design and/or requirements for the design options; this was determined by gathering data through surveys of university students in Turkey. From the analysis of the data, the first three rows of the most preferred/needed design options of the young consumers for online T-shirt design were designed according to the size of the body, original design, and the determination of the length of the T-shirt. On the other hand, it was determined that the design options that young contractors prefer/need less in an online T-shirt design include printing photos on T-shirts, determining the size and location of the pocket, and printing on the desired area of the T-shirt.

Eight customized T-shirt design websites which continue to operate in Turkey were evaluated with respect to their state and condition of offering design options to consumers and customers determined within the scope of the study. As a result of the evaluation, it was determined that the related web sites were found sufficient in terms of the design option according to the body size measurements while the related web sites had partial competence in terms of other options.

According to the results of correlation analysis; the design options that online personalized T-shirt design websites intend to offer do not change according to the age and income of young consumers. However, some design options have a relationship with the gender and education of young consumers. The identified relationship is significant and negative. For gender, the relationship exists with the wide variety of fabric, wide range of fabric colors, determining the length of the shirt, identifying auxiliary materials, determination of pocket size and location, and original design. For income, the relationship exists with wide variety of T-shirt cuts, determining the length of the T-shirt, determining the sleeve length of the T-shirt and printing photos on a T-shirt.

\section{ACKNOWLEDGMENTS}

I would like to convey my thanks and gratitude to Assoc. Prof. Dr. Aytaç Yildiz, Dr. Asım Topakli and Teaching Assistant Naile Erdoğan who had contributed to this study.

\section{REFERENCES}

[1] Satam, D., Liu, Y., Lee, H.J., Intelligent design systems for apparel mass customization, In: The Journal of The Textile Institute, 2011, 102, 4, 353-365

[2] Zhao, Y., Manufacturing personalization models based on industrial big data, In: Journal of Discrete Mathematical Sciences and Cryptography, 2018, 21, 6, 1287-1292

[3] Matthews, D., Rothenberg, L., Gopalakrishnan, S., The impact of mass customization on fashion-innovative students: an assessment of need for uniqueness, self-identity, and perceived performance risk, In: International Journal of Fashion Design, Technology and Education, 2019, 1-8

[4] De Silva, R.K.J., Rupasinghe, T.D., Apeagyei, P., A collaborative apparel new product development process model using virtual reality and augmented reality technologies as enablers, In: International Journal of Fashion Design, Technology and Education, 2019, 12, 1, 1-11

[5] Liang, Y., Liu, C., Comparison of consumers' acceptance of online apparel mass customization across web and mobile channels, In: Journal of Global Fashion Marketing, 2019, 10, 3, 228-245

[6] Piller, F.T., Moeslein, K., Stotko, C.M., Does mass customization pay? An economic approach to evaluate customer integration, In: Production planning \& control, 2004, 15, 4, 435-444 
[7] Wu, J., Co-design communities online: turning public creativity into wearable and sellable fashions, In: Fashion Practice, 2010, 2, 1, 85-104

[8] Li, P., Yu, C., Wu, C., Customer-centered co-design modularization: the skirt design on mobile application, In: The Journal of The Textile Institute, 2019, 1-7

[9] Bulgun, E.Y., Kut, A., An Internet Oriented Custom-Fit Production Approach for Apparel Industry, In: Journal of Organizational Computing and Electronic Commerce, 2005, 15, 4, 285-293

[10] Lee, H.H., Damhorst, M.L., Campbell, J.R., Loker, S., Parsons, J.L., Consumer satisfaction with a mass customized Internet apparel shopping site, In: International Journal of Consumer Studies, 2011, 35, 3, 316-329

[11] Nayak, R., Padhye, R., Wang, L., Chatterjee, K., Gupta, S., The role of mass customisation in the apparel industry, In: International Journal of Fashion Design, Technology and Education, 2015, 8, 2, 162-172

[12] Liang, Y., Websites Vs. Apps: A Comparison of Consumer Acceptance of Apparel Mass-Customization Across Channels, Louisiana State University, Doctoral Dissertations, 2016

[13] Bhaduri, G., Kim, J., "Just for you": Unveiling the Traits of the Mass-Customized Clothing Shoppers, In: International Textile and Apparel Association (ITAA) Annual Conference Proceedings, 2018, 45

[14] Bhaduri, G., Kim, J., Impact of Individual's Regulatory Focus on Value Perceptions of and Willingness to Invest towards Online Mass-Customized Fashion, In: Industry and Education, 2018, 16, 1, 1-18

[15] Yang, J. H., Chen-Yu, J., Consumer Characteristics and Purchase Intentions of Mass-customized Men's Dress Shirts, In: International Textile and Apparel Association (ITAA) Annual Conference Proceedings, 2014, 94

[16] Kang, J.Y.M., Kim, E., e-Mass customisation apparel shopping: effects of desire for unique consumer products and perceived risk on purchase intentions, In: International Journal of Fashion Design, Technology and Education, 2012, 5, 2, 91-103

[17] Zhang, Y., Li, L., Xing, X., Research on Collaborative Design Method for Apparel Mass Customization in the Internet Plus Era, In: International Journal of Economics, Finance and Management Sciences, 2016, 4, 6, 369-377

[18] Yeung, H.T., Choi, T.M. Mass customisation in the Hong Kong apparel industry, In: Production Planning \& Control, 2011, 22, 3, 298-307

[19] Park, M., Yoo, J., Benefits of mass customized products: moderating role of product involvement and fashion innovativeness, In: Heliyon, 2018, 4, 2, e00537

[20] Larsson, J., Customer perspective on mass-customized knitwear, In: Fashion Practice, 2012, 4, 2, 177-195

[21] Ribeiro, L.S., Duarte, P.A.O., Miguel, R., Online consumer behaviour of mass-customised apparel products: $A$ hierarchy of traits approach, In: Journal of Fashion Marketing and Management, 2017, 21, 2, 158-171

[22] Kim, D.E., LaBat, K., Consumer experience in using 3D virtual garment simulation technology, In: Journal of the Textile Institute, 2013, 104, 8, 819-829

[23] Özbek, A., Topaklı, A., Online Mass Customized T-shirt Design, In: Vocational Education (NWSAVE), 2019, 14, 3, $1-10$

[24] Dellaert, B.G., Dabholkar, P.A., Increasing the attractiveness of mass customization: The role of complementary on-line services and range of options, In: International Journal of Electronic Commerce, 2009, 13, 3, 43-70

[25] Peterson, J., Larsson, J., Carlsson, J., Andersson, P., Knit on demand-development and simulation of a production and shop model for customised knitted garments, In: International Journal of Fashion Design, Technology and Education, 2008, 1, 2, 89-99

[26] Khan, T., Syed, A.H., Hashmi, A., An E-Commerce based Web Portal to Support Customize Clothes for Obese People, In: VFAST Trans. Softw. Eng, 2016, 10, 2

[27] Esmer, Y, Pabuçcu, H., Strategic Career Planning: Fuzzy Logic Approach, In: İzmir Journal of Economics, 2019, 34, 1, 111-124, https://doi.org/10.24988/ije.2019341835

[28] Türkiye İstatistik Kurumunun (TÜIK), Istatistiklerle Gençlik 2017, Available at: http://www.tuik.gov.tr/PreHaber Bultenleri.do?id=27598 [Accesed February 2019]

[29] Yüksek Öğretim Bilgi Yönetim Sistemi, Öğrenim Düzeyine Göre Öğrenci Sayısı, Available at: https://istatistik. yok.gov.tr/ [Accesed February 2019]

[30] Yayla, A.Y., Yıldız, A., How Product Development Accelerating Approaches Influence Product Development Performance - An Empirical Study in Turkish Automotive Sub-Industry, In: European Journal of Social Sciences, $2010,18,2$

Author:

\section{AHMET ÖZBEK}

Marmara University, Faculty of Technology, Textile Engineering Department, Göztepe Kampüsü, 34722, Kadıköy - İstanbul, Turkey

Corresponding author:

AHMET ÖZBEK

e-mail: aozbek@marmara.edu.tr 